\title{
Effects of Integrating Cultivar Resistance and Fungicide Application on Fusarium Head Blight and Deoxynivalenol in Winter Wheat
}

Stephen N. Wegulo, Department of Plant Pathology, University of Nebraska-Lincoln, Lincoln 68583; William W. Bockus, Department of Plant Pathology, Kansas State University, Manhattan 66506; John Hernandez Nopsa, Department of Plant Pathology, University of Nebraska-Lincoln, Lincoln 68583; Erick D. De Wolf, Department of Plant Pathology, Kansas State University, Manhattan 66506; Kent M. Eskridge, Department of Statistics, University of Nebraska-Lincoln, Lincoln 68583; Kamaranga H. S. Peiris, Department of Biological and Agricultural Engineering, Kansas State University, Manhattan 66506; and Floyd E. Dowell, USDA ARS Center for Grain and Animal Health Research, Engineering and Wind Erosion Research Unit, Manhattan, KS 66502

\begin{abstract}
Wegulo, S. N., Bockus, W. W., Hernandez Nopsa, J., De Wolf, E. D., Eskridge, K. M., Peiris, K. H. S., and Dowell, F. E. 2011. Effects of integrating cultivar resistance and fungicide application on Fusarium head blight and deoxynivalenol in winter wheat. Plant Dis. 95:554-560.

Fusarium head blight (FHB) or scab, incited by Fusarium graminearum, can cause significant economic losses in small grain production. Five field experiments were conducted from 2007 to 2009 to determine the effects on FHB and the associated mycotoxin deoxynivalenol (DON) of integrating winter wheat cultivar resistance and fungicide application. Other variables measured were yield and the percentage of Fusarium-damaged kernels (FDK). The fungicides prothioconazole + tebuconazole (formulated as Prosaro 421 SC) were applied at the rate of 0.475 liters/ha, or not applied, to three cultivars (experiments 1 to 3 ) or six cultivars (experiments 4 and 5) differing in their levels of resistance to FHB and DON accumulation. The effect of cultivar on FHB index was highly significant $(P<0.0001)$ in all five experiments. Under the highest FHB intensity and no fungicide application, the moderately resistant cultivars Harry, Heyne, Roane, and Truman had less severe FHB than the susceptible cultivars 2137, Jagalene, Overley, and

Tomahawk (indices of 30 to $46 \%$ and 78 to $99 \%$, respectively). Percent fungicide efficacy in reducing index and DON was greater in moderately resistant than in susceptible cultivars. Yield was negatively correlated with index, with FDK, and with DON, whereas index was positively correlated with FDK and with DON, and FDK and DON were positively correlated. Correlation between index and DON, index and FDK, and FDK and DON was stronger in susceptible than in moderately resistant cultivars, whereas the negative correlation between yield and FDK and yield and DON was stronger in moderately resistant than in susceptible cultivars. Overall, the strongest correlation was between index and DON $(0.74 \leq R \leq 0.88, P \leq 0.05)$. The results from this study indicate that fungicide efficacy in reducing FHB and DON was greater in moderately resistant cultivars than in susceptible ones. This shows that integrating cultivar resistance with fungicide application can be an effective strategy for management of FHB and DON in winter wheat.
\end{abstract}

Fusarium head blight (FHB), also known as scab, is a destructive disease of wheat and other small grain cereals. In North America, it is caused mainly by Fusarium graminearum Schwabe (sexual stage Gibberella zeae (Schwein.) Petch), but other species in the genus Fusarium are causal agents (2). Since the early 1990s, FHB has occurred regularly in the United States in most of the areas that produce hard red spring, soft red winter, hard red winter, and durum wheat, and it is now considered one of the most important diseases of wheat in the United States (2). Detrimental effects of FHB include reduction in yield and grain quality, presence of Fusarium-damaged kernels (FDK), and production of the mycotoxin deoxynivalenol (DON) in grain (10).

Several strategies have been used to manage FHB and DON, including crop rotation, genetic resistance, and chemical and biological control (16). Mesterhazy et al. (14) demonstrated the effect of genotype (cultivar) on DON accumulation in winter wheat. They found highly susceptible genotypes to have low to moderate accumulation, compared to little or no accumulation of the mycotoxin in the most resistant genotypes.

Several studies have assessed the efficacy of fungicides for control of FHB and reduction in DON accumulation $(5,7,8,12,15)$. Although fungicides have shown some effectiveness in controlling FHB and DON $(12,13)$, results from fungicide efficacy trials have

Corresponding author: Stephen N. Wegulo,

E-mail: swegulo2@unlnotes.unl.edu

Accepted for publication 21 December 2010.

doi:10.1094/PDIS-07-10-0495

(C) 2011 The American Phytopathological Society been variable. This variability has been attributed in part to fungicide timing and efficacy, cultivar resistance, and application technology $(10,13)$.

Few studies have been done to determine the effect of multiple management strategies on FHB and DON. Koch et al. (9) found that tillage type, cultivar, and application of the fungicide tebuconazole had a significant effect on DON accumulation. As compared to clean tillage, reduced tillage resulted in higher DON content in both a moderately resistant and a highly susceptible cultivar, with the highly susceptible cultivar accumulating more DON than the moderately resistant cultivar. Fungicide application reduced DON concentration only slightly in the moderately resistant cultivar, but significantly in the highly susceptible cultivar. In contrast, Mesterhazy et al. (13) found that fungicide efficacy in controlling FHB and DON accumulation was greater in more resistant than in more susceptible winter wheat cultivars. Horsley et al. (6) applied tebuconazole to 13 barley genotypes with varying levels of FHB resistance. They found the response to tebuconazole of moderately resistant genotypes to be inconsistent for FHB severity and DON accumulation. They also found that tebuconazole applied to moderately resistant genotypes did not consistently reduce DON to acceptable levels.

The association between FHB intensity (incidence, severity, or index $=$ incidence $\times$ severity) and DON in small grains has been studied extensively. Understanding the relationship between DON and FHB intensity can be useful in developing DON predictive models which can in turn be used in managing FHB and DON. Paul et al. (17) analyzed 163 studies and found more than $65 \%$ of all correlation coefficients between FHB intensity and DON to be $>0.50$. This analysis showed that the strongest relationship was between FDK and DON, followed by index and DON. Additionally, it was shown that correlations between FHB intensity and 
DON were significantly affected by wheat type, study type, and study location. However, analyses to determine the effect of cultivar resistance/susceptibility on the relationships among FHB intensity, FDK, DON, and yield have not been done. Information from such analyses can enable researchers to choose wheat cultivars suited for studies aimed at modeling these relationships.

The objectives of this study were to (i) evaluate the effects of integrating cultivar resistance and fungicide application on FHB and DON in winter wheat, (ii) assess differences in winter wheat cultivar reaction to FHB and DON accumulation, (iii) model the relationships among FHB index, FDK, DON, and yield in winter wheat, and (iv) determine if these relationships are affected by cultivar resistance/susceptibility.

\section{Materials and Methods}

From 2007 to 2009, five experiments were conducted at Manhattan, KS, and Mead, NE. The objectives of the experiments were as stated above. Standard agronomic practices for wheat production were followed at each location.

Experiment 1, 2007, Kansas. The experiment was established in Chase silty clay loam soil at Manhattan, KS in fall 2006. Seed of winter wheat cultivars 2137 (FHB-susceptible), Harry (moderately resistant), and Jagalene (susceptible) was sown on 2 October 2006 with a cone-type planter at the rate of $67.25 \mathrm{~kg} / \mathrm{ha}$. Plot size was $1.5 \times 4.6 \mathrm{~m}$. FHB-susceptibility/resistance of the three cultivars was determined from the authors' experience.

Air-dried corn-kernel inoculum (corn kernels colonized by $F$. graminearum) was applied to the soil surface of all plots on 1 April, 15 April, and 1 May at a total application rate of $0.74 \mathrm{~g} / \mathrm{m}^{2}$. Natural rainfall rehydrated the corn-kernel inoculum and initiated fungal development. During anthesis, heads were kept wet with overhead, impulse sprinklers applying water $3 \mathrm{~min}$ of every hour from 9:00 P.M. until 6:00 A.M. Fungicide applications were made at the rate of 187 liters/ha with a pressure of $207 \mathrm{kPa}$, using a backpack sprayer equipped with flat-fan nozzles angled forward about $30^{\circ}$. The experimental design was a split plot in randomized complete blocks with six replicates. Main plots were cultivars and subplots were two fungicide treatments: (i) prothioconazole + tebuconazole (Prosaro $421 \mathrm{SC}$ ) applied at 0.475 liters/ha at Zadoks growth stage 59 (GS 59, emergence of inflorescence complete) (22), and (ii) the check (no fungicide applied). Jagalene and 2137 were at GS 59 on 11 May, whereas Harry was at the same growth stage on 21 May. Induce nonionic surfactant (Helena Chemical Company, Collierville, TN) was added to the fungicide at $0.125 \%$ $\mathrm{vol} / \mathrm{vol}$.

FHB index was assessed on 9 June 2007 by visually estimating the percentage of spikelets that were blighted in each plot. Plots were harvested on 30 June 2007 with a small-plot combine. Tengram subsamples of harvested grain were each spread out in a shallow weigh-boat and visually assessed for percent FDK. They were then ground to flour and sent to the North Dakota Veterinary Diagnostic Laboratory at North Dakota State University for DON content determination by gas chromatography with electron capture detection (GC/ECD) (20).

Experiments 2 and 3, 2008 and 2009, Nebraska. The experiments were established in deep silty clay loam soil at Mead, NE in fall 2007 and 2008. Three cultivars (2137, Harry, and Jagalene) were planted on 27 October 2007 and 3 October 2008 following corn at the University of Nebraska Agricultural Research and Development Center at Mead. Seeding rate was 80 $\mathrm{kg} / \mathrm{ha}$ in 2007 and $101 \mathrm{~kg} / \mathrm{ha}$ in 2008.

Corn kernels colonized by $F$. graminearum were applied to the soil surface in the wheat plots 1 week before flowering at a rate of $0.42 \mathrm{~g} / \mathrm{m}^{2}$. Plots were not irrigated. Natural rainfall rehydrated the corn-kernel inoculum and initiated fungal development. There also was abundant natural inoculum in 2008. The experimental design was a split plot in randomized complete blocks with six replications. The main plots were cultivars and the subplots were fungicide treatments (check or treated with prothioconazole + tebuconazole (Prosaro 421 SC) + Induce nonionic surfactant at
$0.125 \% \mathrm{vol} / \mathrm{vol}$ applied 2 days before GS 65 (mid-anthesis) at a rate of $0.475 \mathrm{liter} / \mathrm{ha}$. Plot size was $1.5 \times 6 \mathrm{~m}$. $\mathrm{A} \mathrm{CO}_{2}$-powered backpack sprayer $(241 \mathrm{kPa})$ and four Teejet $800-1 \mathrm{VS}$ nozzles spaced $30.5 \mathrm{~cm}$ apart on a boom were used to apply fungicide to spikes. Each cultivar was inoculated at mid-anthesis with spores of F. graminearum $\left(1 \times 10^{5}\right.$ spores $\left./ \mathrm{ml}\right)$ using a hand-pumped backpack sprayer. Mid-anthesis was considered to be the day on which $50 \%$ of the spikes of a given cultivar had extruded anthers. Thus, cultivars were inoculated on different dates within a season ranging from 28 May to 4 June.

Disease severity and incidence were assessed on 50 randomly selected spikes in each plot on 30 June 2008 and 20 June 2009 and used to calculate FHB index using the formula index $=$ [incidence $(\%) \times$ severity $(\%)] / 100$. Plots were harvested with a small plot combine. Percent FDK was measured with an automated singlekernel near-infrared (SKNIR, Perten Instruments, Stockhom, Sweden) system at the USDA-ARS Center for Grain and Animal Health Research, Engineering and Wind Erosion Research Unit, Manhattan, KS. Accuracy of the SKNIR system to measure FDK in winter wheat has been validated (21). A 10-g grain sample from each plot was ground to flour and submitted to the North Dakota Veterinary Diagnostic Laboratory at North Dakota State University for DON content determination using gas chromatography with electron capture detection (GC/ECD) (20).

Experiments 4 and 5, 2008 and 2009, Kansas. The experiments were conducted at Manhattan, KS in 2008 and 2009. The methods were the same as in experiment 1, 2007 including the dates corn-kernel inoculum was applied, except that the cultivars were Heyne, Karl 92, Overley, Roane, Tomahawk, and Truman. In 2008, full heading (GS 59) in these cultivars occurred on 15 May (Karl 92 and Overley), 19 May (Roane and Tomahawk), and 23 May (Heyne and Truman). In 2009, full heading occurred on 10 May (Karl 92 and Overley), 12 May (Roane), 14 May (Heyne and Tomahawk), and 15 May (Truman). In the 2008 experiment, the planting date was 5 October 2007 and FHB index was assessed on 9 June 2008. In the 2009 experiment, the planting date was 2 October 2008 and FHB index was assessed on 8 June 2009.

Comparison of fungicide efficacy in moderately resistant versus susceptible cultivars. To compare fungicide efficacy for index, yield, FDK, and DON in moderately resistant versus susceptible cultivars, replicate data from four moderately resistant cultivars (Harry, Heyne, Roane, and Truman) and four susceptible cultivars (2137, Jagalene, Overley, and Tomahawk) were used. Moderately resistant and susceptible cultivars used in this comparison were determined from the authors' experience and Kansas State University ratings (1). These data were from location-years that had high levels of FHB (Manhattan 2007 and Mead 2008 [experiments 1 and 2] and Manhattan 2008 and 2009 [experiments 4 and 5]). To ensure equal representation of cultivars, four replicates from each location-year were used (for location-years that had six replicates, only the first four replicates were used). Moderately resistant cultivars were grouped into one treatment (resistant treatment), and susceptible cultivars were grouped into a second treatment (susceptible treatment). Each cultivar/location-year combination was considered a replicate. There were 32 replicates in each of the two treatments.

Data analysis. Data were analyzed by the general linear models (GLM) procedure of SAS version 9.2 (SAS Institute, Cary, NC). The least significant difference (LSD, $P=0.05$ ) (3) was used to compare pairs of treatment means. Throughout this paper, when comparing treatment means, use of "higher", "lower", "differed", "did not differ", "reduced", or "increased" is in reference to the LSD at $P=0.05 . F$ values for main plot (cultivar) and subplot (fungicide treatment) effects and their interaction were considered significant at $P \leq 0.05$.

Fungicide efficacy for index, FDK, and DON for each cultivar was calculated as

$$
[(C-F) / C]^{*} 100
$$


where $C$ is the check treatment value and $F$ is the fungicide treatment value. Fungicide efficacy for yield for each cultivar was calculated as

$$
[(F-C) / F]^{*} 100
$$

where $C$ and $F$ are as defined above.

Cultivar means from experiments 1 to 3 and experiments 4 and 5 were used in analysis of correlation $(3,19)$ between index and yield, index and FDK, index and DON, yield and FDK, yield and DON, and FDK and DON. To determine if there was consistency in the relationships among index, yield, FDK, and DON, these correlations were evaluated four times using cultivar means (i) averaged over all fungicide treatments, (ii) from fungicide treatments only, (iii) from check treatments only, and (iv) from fungicide treatments + check treatments. To determine the effect of cultivar resistance/ susceptibility on the relationships among index, yield, FDK, and DON, the correlations were repeated using combined means from susceptible cultivars (2137, Jagalene, Overley, and Tomahawk) and moderately resistant cultivars (Harry, Heyne, Roane, and Truman).

\section{Results}

Experiments 1 to 3, 2007 to 2009. $F$ values for cultivar $\times$ fungicide interaction were significant $(P \leq 0.0229)$ for index and yield in 2007 and FDK and DON in 2009 (Table 1). The effect of cultivar was significant for all measured variables except FDK and DON in 2007 and yield in 2009. The effect of fungicide was significant for index, yield, and DON in 2007; FDK in 2008; and yield, FDK, and DON in 2009 (Table 1). Therefore, the only consistent effect in all 3 years was that of cultivar on index $(P<$ $0.0001)$. Neither cultivar nor fungicide had a consistent effect on yield, FDK, or DON over the 3-year period.

A comparison of fungicide treatment means (Prosaro and check) by cultivar showed that in 2007, Prosaro significantly reduced FHB index and increased yield in all three cultivars, but reduced FDK and DON only in Harry (Table 2). In 2008, Prosaro reduced FDK in Jagalene and 2137. In 2009, Prosaro did not reduce index in any cultivar. However, it increased yield in Jagalene, reduced FDK in Harry and Jagalene, and reduced DON in Harry (Table 2). In 2007 and 2008 (high FHB intensity), index was consistently highest in Jagalene and lowest in Harry in both the Prosaro and check treatments. However, despite the low index in Harry, the level of DON in this cultivar was similar to DON levels in the susceptible 2137 and Jagalene. FDK in the check treatment was consistently highest in Harry in all three years (Table 2).

Differences among cultivars in fungicide efficacy (percent reduction in index, FDK, and DON and percent increase in yield)

Table 1. Analysis of variance from experiments conducted to determine the effect of combining cultivar resistance and fungicide application on Fusarium head blight (FHB) index, yield, Fusarium-damaged kernels (FDK), and deoxynivalenol (DON) concentration in winter wheat, 2007 to 2009

\begin{tabular}{|c|c|c|c|c|c|c|c|c|c|}
\hline \multirow[b]{2}{*}{ Source of variation } & \multirow[b]{2}{*}{$\mathbf{d f}^{\mathrm{x}}$} & \multicolumn{2}{|c|}{$\operatorname{Index}^{\mathrm{w}}(\%)$} & \multicolumn{2}{|c|}{ Yield (kg/ha) } & \multicolumn{2}{|c|}{ FDK $(\%)$} & \multicolumn{2}{|c|}{ DON (ppm) } \\
\hline & & $\mathbf{M S}^{\mathbf{y}}$ & $P>F$ & MS & $P>F$ & MS & $P>F$ & MS & $P>F$ \\
\hline \multicolumn{10}{|l|}{ Experiment $1^{\mathrm{z}}, 2007$} \\
\hline Rep & 5 & 52 & 0.8246 & 90,309 & 0.1573 & 47 & 0.9819 & 16.0 & 0.5509 \\
\hline Cultivar (C) & 2 & 8,695 & $<0.0001$ & 293,615 & 0.0146 & 386 & 0.3825 & 5.7 & 0.7485 \\
\hline Error (a) & 10 & 124 & 0.0509 & 44,193 & 0.0008 & 364 & 0.1869 & 19.0 & 0.2613 \\
\hline Fungicide (F) & 1 & 6,751 & $<0.0001$ & $1,653,322$ & $<0.0001$ & 851 & 0.0692 & 102.3 & 0.0145 \\
\hline $\mathrm{C} \times \mathrm{F}$ & 2 & 327 & 0.0084 & 33,989 & 0.0229 & 753 & 0.0610 & 47.6 & 0.0544 \\
\hline Error (b) & 15 & 49 & & 6,927 & & 222 & & 13.4 & \\
\hline Total & 35 & & & & & & & & \\
\hline \multicolumn{10}{|l|}{ Experiment 2, 2008} \\
\hline Rep & 5 & 502 & 0.0043 & $1,535,558$ & 0.0661 & 194 & 0.0282 & 19.5 & 0.0447 \\
\hline Cultivar (C) & 2 & 1,926 & $<0.0001$ & $9,660,748$ & 0.0004 & 873 & 0.0005 & 81.9 & 0.0011 \\
\hline Error (a) & 10 & 70 & 0.5265 & 513,606 & 0.4739 & 48 & 0.6048 & 5.6 & 0.2068 \\
\hline Fungicide $(\mathrm{F})$ & 1 & 10 & 0.7146 & $2,195,558$ & 0.0547 & 851 & 0.0016 & 13.9 & 0.0667 \\
\hline $\mathrm{C} \times \mathrm{F}$ & 2 & 23 & 0.7363 & 173,600 & 0.7148 & 26 & 0.6485 & 6.0 & 0.2169 \\
\hline Error (b) & 15 & 74 & & 505,602 & & 57 & & 3.6 & \\
\hline Total & 35 & & & & & & & & \\
\hline \multicolumn{10}{|l|}{ Experiment 3, 2009} \\
\hline Rep & 4 & 2 & 0.7558 & 170,510 & 0.5962 & 57 & 0.4381 & 0.5 & 0.4585 \\
\hline Cultivar (C) & 2 & 257 & $<0.0001$ & 409,749 & 0.2336 & 1,651 & 0.0002 & 43.5 & $<0.0001$ \\
\hline Error (a) & 8 & 37 & 0.0322 & 233,629 & 0.2718 & 54 & 0.1764 & 0.5 & 0.4526 \\
\hline Fungicide (F) & 1 & 5 & 0.0748 & $1,880,917$ & 0.0051 & 1,428 & $<0.0001$ & 7.6 & 0.0019 \\
\hline $\mathrm{C} \times \mathrm{F}$ & 2 & 1 & 0.4688 & 266,118 & 0.2330 & 303 & 0.0028 & 4.2 & 0.0047 \\
\hline Error (b) & 12 & 1 & & 161,412 & & 30 & & 0.5 & \\
\hline Total & 29 & & & & & & & & \\
\hline \multicolumn{10}{|l|}{ Experiment 4, 2008} \\
\hline Rep & 3 & 104 & 0.2276 & 421,996 & 0.0030 & 15 & 0.9612 & 65.3 & 0.0385 \\
\hline Cultivar (C) & 5 & 7,768 & $<0.0001$ & $16,264,103$ & $<0.0001$ & 5,036 & $<0.0001$ & 851.5 & $<0.0001$ \\
\hline Error (a) & 15 & 64 & 0.0048 & 57,758 & 0.5055 & 155 & 0.0300 & 18.1 & 0.6287 \\
\hline Fungicide (F) & 1 & 3,088 & $<0.0001$ & $5,406,364$ & $<0.0001$ & 574 & 0.0064 & 289.6 & 0.0018 \\
\hline $\mathrm{C} \times \mathrm{F}$ & 5 & 56 & 0.0293 & 253,659 & 0.0092 & 87 & 0.2559 & 62.2 & 0.0435 \\
\hline Error (b) & 18 & 17 & & 58,601 & & 60 & & 21.5 & \\
\hline Total & 47 & & & & & & & & \\
\hline \multicolumn{10}{|l|}{ Experiment 5, 2009} \\
\hline Rep & 3 & 47 & 0.6260 & 339,266 & 0.2313 & 81 & 0.5409 & 6.0 & 0.9252 \\
\hline Cultivar (C) & 5 & 1,504 & $<0.0001$ & $2,801,732$ & $<0.0001$ & 2,213 & $<0.0001$ & 401.9 & 0.0002 \\
\hline Error (a) & 15 & 79 & 0.0015 & 212,087 & 0.2294 & 109 & 0.5403 & 38.8 & 0.0271 \\
\hline Fungicide $(\mathrm{F})$ & 1 & 3,906 & $<0.0001$ & $1,871,064$ & 0.0022 & 276 & 0.1392 & 392.2 & $<0.0001$ \\
\hline $\mathrm{C} \times \mathrm{F}$ & 5 & 199 & $<0.0001$ & 288,362 & 0.1347 & 68 & 0.7071 & 16.3 & 0.3930 \\
\hline Error (b) & 18 & 17 & & 147,480 & & 115 & & 14.8 & \\
\hline Total & 47 & & & & & & & & \\
\hline
\end{tabular}

${ }^{\mathrm{w}}$ Index was calculated as [FHB incidence $(\%) \times$ FHB severity $\left.(\%)\right] / 100$.

${ }^{x}$ Degrees of freedom.

${ }^{y}$ Mean square.

${ }^{\mathrm{z}}$ Experiments 1 to 5 were conducted at Manhattan, KS in 2007; Mead, NE in 2008; Mead in 2009; Manhattan in 2008; and Manhattan in 2009, respectively. 
varied from year to year (Table 3). In 2007, efficacy for all variables was highest in Harry, although the efficacy for DON did not significantly differ among the three cultivars. In 2008, efficacy did not differ among cultivars for any variable. In 2009, efficacy was not computed for index and DON due to low values for these variables. Efficacy for yield did not differ among cultivars, but was higher for FDK in Jagalene than in 2137 (Table 3).

Experiments 4 and 5, 2008 and 2009. $F$ values for cultivar $\times$ fungicide interaction were significant $(P \leq 0.0435)$ for index, yield, and DON in 2008 and index in 2009 (Table 1). In both years, the effect of cultivar on all measured variables (index, yield, FDK, and DON) was highly significant $(P \leq 0.0002)$. The effect of fungicide was significant for all variables $(P \leq 0.0064)$ in both years except FDK in 2009.

A comparison of fungicide treatment means by cultivar showed that in 2008, Prosaro reduced index in all cultivars except Tomahawk, and in 2009 it reduced index in all cultivars (Table 4). In 2008, Prosaro reduced FDK only in Heyne; reduced DON in
Heyne, Overley, and Truman; and increased yield in all cultivars except Tomahawk. In 2009, Prosaro did not reduce FDK in any cultivar, but reduced DON in Overley and Truman. It increased yield only in Overley (Table 4). In both the Prosaro and check treatments and in both years, index, FDK, and DON were highest in Tomahawk and Overley and lowest in Truman. The highest and lowest yield in both years occurred in the Prosaro treatment in Truman and the check treatment in Tomahawk, respectively.

In 2008, the effect of cultivar on fungicide efficacy (Table 5) was highly significant for index $(P<0.0001)$, FDK $(P=0.0005)$, and DON $(P=0.0021)$. Although the effect of cultivar on fungicide efficacy was not significant for yield $(P=0.3580)$, efficacy in Roane was significantly lower than efficacy in Heyne based on the LSD test at $P=0.05$. Efficacy for index, FDK, and DON was highest in Truman and lowest in Tomahawk. In 2009, the effect of cultivar on fungicide efficacy was not significant for any variable. However, the LSD test at $P=0.05$ showed that efficacy for yield was lower in Roane than in all other cultivars (Table 5).

Table 2. Fungicide treatment means by cultivar for Fusarium head blight (FHB) index, yield, Fusarium-damaged kernels (FDK), and deoxynivalenol (DON) concentration from experiments 1 to 3 conducted to determine the effect of combining cultivar resistance and fungicide application on FHB, yield, FDK, and DON in winter wheat, 2007 to 2009

\begin{tabular}{|c|c|c|c|c|c|c|c|c|c|c|c|c|c|}
\hline \multirow[b]{2}{*}{ Cultivar } & \multirow[b]{2}{*}{$\begin{array}{l}\text { Fungicide } \\
\text { treatment }\end{array}$} & \multicolumn{4}{|c|}{ Manhattan, KS 2007y } & \multicolumn{4}{|c|}{ Mead, NE 2008} & \multicolumn{4}{|c|}{ Mead, NE 2009} \\
\hline & & $\begin{array}{c}\operatorname{Index}^{\mathrm{Z}} \\
(\%)\end{array}$ & $\begin{array}{c}\text { Yield } \\
\text { (kg/ha) }\end{array}$ & $\begin{array}{c}\text { FDK } \\
(\%)\end{array}$ & $\begin{array}{l}\text { DON } \\
(\mathbf{p p m})\end{array}$ & $\begin{array}{c}\text { Index } \\
(\%)\end{array}$ & $\begin{array}{c}\text { Yield } \\
\text { (kg/ha) }\end{array}$ & $\begin{array}{c}\text { FDK } \\
(\%)\end{array}$ & $\begin{array}{l}\text { DON } \\
(\mathbf{p p m})\end{array}$ & $\begin{array}{c}\text { Index } \\
(\%)\end{array}$ & $\begin{array}{c}\text { Yield } \\
\text { (kg/ha) }\end{array}$ & $\begin{array}{c}\text { FDK } \\
(\%)\end{array}$ & $\begin{array}{c}\text { DON } \\
\text { (ppm) }\end{array}$ \\
\hline Harry & Check & $46.0 \mathrm{c}$ & $544 \mathrm{~d}$ & $55.0 \mathrm{a}$ & $22.5 \mathrm{a}$ & $37.1 \mathrm{c}$ & $1,938 \mathrm{bc}$ & $57.2 \mathrm{ab}$ & $13.5 \mathrm{a}$ & $10.3 \mathrm{a}$ & 1,979 a-c & $54.0 \mathrm{a}$ & $5.4 \mathrm{a}$ \\
\hline Harry & Prosaro & $6.7 \mathrm{~d}$ & $1,095 \mathrm{ab}$ & & & $39.2 \mathrm{c}$ & $2,441 \mathrm{ab}$ & $50.3 \mathrm{bc}$ & $13.8 \mathrm{a}$ & & $2,444 \mathrm{a}$ & $40.2 \mathrm{~b}$ & $2.9 \mathrm{~b}$ \\
\hline Jagalene & Check & $87.5 \mathrm{a}$ & $589 \mathrm{~d}$ & $36.7 \mathrm{ab}$ & $20.1 \mathrm{ab}$ & $64.3 \mathrm{a}$ & $961 \mathrm{~d}$ & $61.0 \mathrm{a}$ & $15.0 \mathrm{a}$ & $0.7 \mathrm{~b}$ & $1,466 \mathrm{c}$ & $41.0 \mathrm{~b}$ & $0.7 \mathrm{c}$ \\
\hline Jagalene & Prosaro & $67.5 \mathrm{~b}$ & $945 b c$ & $42.5 \mathrm{ab}$ & $18.0 \mathrm{a}-\mathrm{c}$ & $62.1 \mathrm{ab}$ & $1,209 \mathrm{~cd}$ & $51.3 \mathrm{bc}$ & $12.6 \mathrm{a}$ & $0.3 \mathrm{~b}$ & $2,309 a b$ & $16.2 \mathrm{c}$ & $0.4 \mathrm{c}$ \\
\hline 2137 & Check & $77.8 \mathrm{ab}$ & $871 \mathrm{c}$ & $55.0 \mathrm{a}$ & $17.8 \mathrm{bc}$ & $55.3 \mathrm{ab}$ & $2,497 \mathrm{ab}$ & $46.7 \mathrm{c}$ & $10.0 \mathrm{~b}$ & $1.3 \mathrm{~b}$ & $1,742 \mathrm{bc}$ & $23.8 \mathrm{c}$ & $0.5 \mathrm{c}$ \\
\hline 2137 & Prosaro & $55.0 \mathrm{c}$ & $1,250 \mathrm{a}$ & $45.8 \mathrm{ab}$ & $17.6 \mathrm{bc}$ & $52.2 \mathrm{~b}$ & $3,227 \mathrm{a}$ & $34.0 \mathrm{~d}$ & $8.4 \mathrm{~b}$ & $0.7 \mathrm{~b}$ & $1,936 \mathrm{a}-\mathrm{c}$ & $21.0 \mathrm{c}$ & $0.3 \mathrm{c}$ \\
\hline
\end{tabular}

${ }^{y}$ Experiments were conducted in three location-years and consisted of three winter wheat cultivars and two fungicide treatments: check and prothioconazole + tebuconazole (Prosaro) applied at 0.475 liter/ha.

${ }^{\mathrm{z}}$ Means followed by the same letter within a column are not different according to Fisher's least significant difference test at $P=0.05$.

Table 3. Fungicide efficacy (\%) among cultivars for Fusarium head blight (FHB) index, Fusarium-damaged kernels (FDK), deoxynivalenol (DON) concentration, and yield from experiments 1 to 3 conducted to determine the effect of combining cultivar resistance and fungicide application on FHB, yield, FDK, and DON in winter wheat, 2007 to 2009

\begin{tabular}{|c|c|c|c|c|c|c|c|c|c|c|c|c|}
\hline \multirow[b]{2}{*}{ Cultivar } & \multicolumn{4}{|c|}{ Manhattan, KS 2007 } & \multicolumn{4}{|c|}{ Mead, NE 2008} & \multicolumn{4}{|c|}{ Mead, NE 2009} \\
\hline & Index $^{y}$ & Yield & FDK & DON & Index & Yield & FDK & DON & Index & Yield & FDK & DON \\
\hline Harry & $85.4 \mathrm{a}$ & $50.3 \mathrm{a}$ & 46.9 a & $34.7 \mathrm{a}$ & $-5.7 \mathrm{a}$ & $20.6 \mathrm{a}$ & $12.1 \mathrm{a}$ & $-2.2 \mathrm{a}$ & $\ldots^{\mathrm{z}}$ & $19.1 \mathrm{a}$ & $25.6 \mathrm{ab}$ & $\ldots^{\mathrm{z}}$ \\
\hline Jagalene & $22.9 \mathrm{~b}$ & $37.7 \mathrm{ab}$ & $-15.8 \mathrm{~b}$ & $10.4 \mathrm{a}$ & $3.4 \mathrm{a}$ & $20.5 \mathrm{a}$ & $15.9 \mathrm{a}$ & $16.0 \mathrm{a}$ & $\ldots$ & $36.5 \mathrm{a}$ & $60.5 \mathrm{a}$ & $\ldots$ \\
\hline 2137 & $29.3 \mathrm{~b}$ & $30.3 \mathrm{~b}$ & $16.7 \mathrm{ab}$ & $1.1 \mathrm{a}$ & $5.6 \mathrm{a}$ & $22.6 \mathrm{a}$ & $27.2 \mathrm{a}$ & $16.0 \mathrm{a}$ & $\ldots$ & $10.0 \mathrm{a}$ & $11.8 \mathrm{~b}$ & $\ldots$ \\
\hline
\end{tabular}

${ }^{x}$ Experiments were conducted in three location-years and consisted of three winter wheat cultivars and two fungicide treatments: check and prothioconazole + tebuconazole (Prosaro) applied at 0.475 liter/ha.

y Means followed by the same letter within a column are not different according to Fisher's least significant difference test at $P=0.05$.

${ }^{\mathrm{z}}$ Efficacy was not calculated because index and DON levels were very low.

Table 4. Fungicide treatment means by cultivar for Fusarium head blight (FHB) index, yield, Fusarium-damaged kernels (FDK), and deoxynivalenol (DON) concentration from experiments 4 and 5 conducted to determine the effect of combining cultivar resistance and fungicide application on FHB, yield, FDK, and DON in winter wheat, 2008 to 2009

\begin{tabular}{|c|c|c|c|c|c|c|c|c|c|}
\hline \multirow[b]{2}{*}{ Cultivar } & \multirow{2}{*}{$\begin{array}{l}\text { Fungicide } \\
\text { treatment }\end{array}$} & \multicolumn{4}{|c|}{$2008^{y}$} & \multicolumn{4}{|c|}{2009} \\
\hline & & $\operatorname{Index}^{\mathrm{z}}(\%)$ & Yield (kg/ha) & FDK $(\%)$ & DON (ppm) & Index (\%) & Yield (kg/ha) & FDK $(\%)$ & DON (ppm) \\
\hline Heyne & Check & $35.0 \mathrm{~d}$ & $1,459 \mathrm{~g}$ & $19.3 \mathrm{e}$ & $26.7 \mathrm{c}$ & $29.8 \mathrm{bc}$ & 2,336 ef & $30.0 \mathrm{~d}-\mathrm{f}$ & $10.9 \mathrm{c}-\mathrm{e}$ \\
\hline Heyne & Prosaro & $20.0 \mathrm{e}$ & $2,420 \mathrm{~d}$ & $4.5 \mathrm{f}$ & $16.5 \mathrm{de}$ & $17.5 \mathrm{de}$ & $2,861 \mathrm{c}-\mathrm{e}$ & $30.0 \mathrm{~d}-\mathrm{f}$ & $6.8 \mathrm{de}$ \\
\hline Karl 92 & Check & $69.5 \mathrm{~b}$ & $1,877 \mathrm{f}$ & $36.3 \mathrm{~cd}$ & $22.9 \mathrm{~cd}$ & $36.0 \mathrm{~b}$ & 3,173 b-d & $41.3 \mathrm{~cd}$ & $9.3 \mathrm{c}-\mathrm{e}$ \\
\hline Karl 92 & Prosaro & $50.3 \mathrm{c}$ & $2,327 \mathrm{de}$ & $23.8 \mathrm{de}$ & $23.7 \mathrm{c}$ & $24.0 \mathrm{~cd}$ & $3,276 \mathrm{bc}$ & $42.5 \mathrm{~cd}$ & $6.9 \mathrm{de}$ \\
\hline Overley & Check & $94.0 \mathrm{a}$ & $1,483 \mathrm{~g}$ & $53.8 \mathrm{ab}$ & $41.8 \mathrm{a}$ & $66.5 \mathrm{a}$ & $2,909 \mathrm{c}-\mathrm{e}$ & $68.8 \mathrm{a}$ & $26.0 \mathrm{a}$ \\
\hline Overley & Prosaro & $75.8 \mathrm{~b}$ & $2,054 \mathrm{ef}$ & $42.5 \mathrm{bc}$ & $33.3 \mathrm{~b}$ & $34.8 \mathrm{~b}$ & $3,882 \mathrm{a}$ & $55.0 \mathrm{a}-\mathrm{c}$ & $15.8 \mathrm{bc}$ \\
\hline Roane & Check & $46.3 \mathrm{c}$ & $3,642 \mathrm{c}$ & $2.0 \mathrm{f}$ & $13.2 \mathrm{ef}$ & $29.0 \mathrm{bc}$ & $3,736 \mathrm{ab}$ & $46.3 \mathrm{bc}$ & $7.7 \mathrm{de}$ \\
\hline Roane & Prosaro & $28.0 \mathrm{de}$ & $4,388 \mathrm{~b}$ & $1.0 \mathrm{f}$ & $7.4 \mathrm{fg}$ & $17.8 \mathrm{de}$ & $3,613 \mathrm{ab}$ & $40.0 \mathrm{c}-\mathrm{e}$ & $3.8 \mathrm{e}$ \\
\hline Tomahawk & Check & $98.5 \mathrm{a}$ & $535 \mathrm{~h}$ & $61.3 \mathrm{a}$ & $23.5 \mathrm{c}$ & $63.0 \mathrm{a}$ & $2,119 \mathrm{f}$ & $62.5 \mathrm{a}$ & $25.0 \mathrm{a}$ \\
\hline Tomahawk & Prosaro & $92.8 \mathrm{a}$ & $692 \mathrm{~h}$ & $61.3 \mathrm{a}$ & $26.7 \mathrm{c}$ & $33.0 \mathrm{bc}$ & $2,642 \mathrm{~d}-\mathrm{f}$ & $61.3 \mathrm{ab}$ & $18.9 \mathrm{ab}$ \\
\hline Truman & Check & $30.0 \mathrm{~d}$ & $3,749 \mathrm{c}$ & $2.5 \mathrm{f}$ & $14.4 \mathrm{e}$ & $23.8 \mathrm{~cd}$ & $3,690 \mathrm{ab}$ & $25.0 \mathrm{ef}$ & $12.5 \mathrm{~b}-\mathrm{d}$ \\
\hline Truman & Prosaro & $10.3 \mathrm{f}$ & $4,891 \mathrm{a}$ & $0.5 \mathrm{f}$ & $5.5 \mathrm{~g}$ & $12.8 \mathrm{e}$ & $4,059 \mathrm{a}$ & $16.3 \mathrm{f}$ & $5.1 \mathrm{e}$ \\
\hline
\end{tabular}

${ }^{y}$ Experiments were conducted at Manhattan, KS in 2008 and 2009 and consisted of six winter wheat cultivars and two fungicide treatments: check and prothioconazole + tebuconazole (Prosaro) applied at 0.475 liter/ha.

${ }^{\mathrm{z}}$ Means followed by the same letter within a column are not different according to Fisher's least significant difference test at $P=0.05$. 
Fungicide efficacy for index, DON, FDK, and yield in moderately resistant versus susceptible cultivars. The effect of cultivar (resistant versus susceptible) on fungicide efficacy was highly significant for index $(P<0.0001)$ and DON $(P=0.0057)$. It was significant for FDK at the $10 \%$ level $(P=0.0903)$; however, it was not significant for yield $(P=0.4175)$. Fungicide efficacy for index and DON was higher in moderately resistant cultivars (Harry, Heyne, Roane, and Truman) than in susceptible cultivars (2137, Jagalene, Overley, and Tomahawk) (Fig. 1).

Correlations among index, yield, FDK, and DON. In all five experiments, there was a consistent, positive correlation between index and DON $(0.74 \leq R \leq 0.88, P \leq 0.05)$ (Table 6). In experiments 4 and 5 , index and yield were consistently negatively correlated $(-0.80 \leq R \leq-0.74, P \leq 0.01)$, as were yield and DON $(-0.78$ $\leq R \leq-0.69, P \leq 0.05)$. There was a stronger relationship between index and DON, index and FDK, and FDK and DON in susceptible cultivars compared to moderately resistant cultivars (Table 7). In contrast, the relationships between yield and FDK and between yield and DON were generally stronger in moderately resistant than in susceptible cultivars.

\section{Discussion}

This study demonstrated higher fungicide efficacy among winter wheat cultivars with moderate resistance to FHB as compared to susceptible cultivars. This implies that in years with high FHB intensity, the disease can be controlled more effectively with fungicide application in moderately resistant than in susceptible cultivars. In years with low to moderate FHB intensity (enough to cause economic loss in susceptible cultivars), it may not be necessary to apply a fungicide to moderately resistant cultivars, as the resistance alone may be effective in preventing economic loss. Therefore, by growing moderately resistant cultivars, a farmer can benefit from more effective control of FHB when conditions favor disease development, and by avoiding fungicide application altogether when low to moderate levels of disease are forecast.

Winter wheat cultivars and the fungicide Prosaro had significant effects on FHB index, DON, FDK, and yield. Although these effects were variable within and among location-years, the overall results were lower index, DON, and FDK and higher yield in moderately resistant cultivars and fungicide-treated plots compared to susceptible cultivars and check plots. The significant cultivar $\times$ fungicide interaction for each measured variable in at least one location-year indicated that the effect of fungicide application on the measured variables varied from cultivar to cultivar, implying that fungicide efficacy in controlling FHB and DON can be greater in some cultivars than in others, as indicated by the higher fungicide efficacy for index, DON, and FDK in the moderately resistant than in the susceptible cultivars (Fig. 1).

In this study, cultivar $\times$ fungicide interactions were not consistently significant. By contrast, Mesterhazy et al. (13) tested fungicides on winter wheat cultivars differing in levels of resistance to FHB and found consistent cultivar $\times$ fungicide interactions for all measured variables (severity, DON, FDK, and yield loss). This may be due to the fact that there were only two fungicide treat- ments in the present study (Prosaro and check), compared to 10 treatments in the study of Mesterhazy et al. (13). In that study, all fungicides reduced FHB, DON, FDK, and yield loss compared to the check treatment. In this study, Prosaro did not consistently reduce index, FDK, and DON or increase yield in experiments 1 to 3. Variability in fungicide efficacy on FHB has been reported by several researchers. Milus and Parsons (15) found that several fungicides, including tebuconazole, did not reduce FHB or DON. Hollingsworth et al. (5) reported that DON accumulation in grain of moderately susceptible and moderately resistant spring wheat cultivars was unchanged by fungicide treatment, whereas Menniti et al. (11) found that the fungicides tebuconazole, prochloraz, and bromuconazole effectively controlled $F$. graminearum and reduced DON in durum wheat. Variability in FHB and DON response to fungicides has been attributed to several factors, including pathogen isolate and fungicide application timing and coverage $(4,13)$.

Prosaro reduced FDK in at least one cultivar in four out of five experiments. In four of the five experiments, there was no significant cultivar $\times$ fungicide interaction for FDK. Ransom and McMullen (18) similarly demonstrated the effectiveness of fungicides in reducing FDK and the lack of cultivar $\times$ fungicide interaction for FDK. The levels of FDK in this study, however, were much higher than those reported by Ransom and McMullen (18), despite similar levels of FHB. This may be due to cultivar differences or the environment. Prosaro also consistently increased yield, and cultivars differed in their yield response in this study, a result similar to results from other studies $(8,13,18)$.

FHB index and DON, index and FDK, and DON and FDK were positively correlated. This result was expected and is consistent with published results $(11,17)$. Paul et al. (17) used meta-analysis to analyze 163 studies reporting correlations between DON and

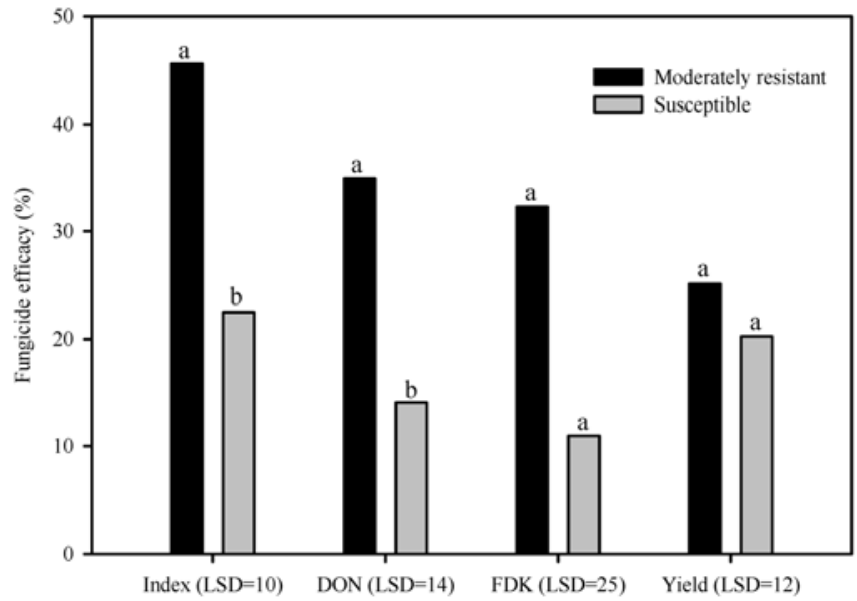

Fig. 1. Fungicide efficacy for Fusarium head blight (FHB) index, deoxynivaleno (DON), Fusarium-damaged kernels (FDK), and yield in moderately resistant and susceptible winter wheat cultivars. Within each variable, values with the same letter are not different according to the least significant difference (LSD) test at $P=0.05$.

Table 5. Fungicide efficacy (\%) among cultivars for Fusarium head blight (FHB) index, Fusarium-damaged kernels (FDK), deoxynivalenol (DON) concentration, and yield from experiments 4 and 5 conducted to determine the effect of combining cultivar resistance and fungicide application on FHB, yield, FDK, and DON in winter wheat, 2008 to 2009

\begin{tabular}{|c|c|c|c|c|c|c|c|c|}
\hline \multirow[b]{2}{*}{ Cultivar } & \multicolumn{4}{|c|}{$2008^{y}$} & \multicolumn{4}{|c|}{2009} \\
\hline & $\operatorname{Index}^{z}$ & Yield & FDK & DON & Index & Yield & FDK & DON \\
\hline Heyne & $42.9 \mathrm{~b}$ & $39.7 \mathrm{a}$ & $76.7 \mathrm{ab}$ & $38.2 \mathrm{ab}$ & $41.7 \mathrm{a}$ & $18.4 \mathrm{a}-\mathrm{c}$ & $0.0 \mathrm{a}$ & $37.6 \mathrm{a}$ \\
\hline Karl 92 & $27.6 \mathrm{~cd}$ & $19.3 \mathrm{ab}$ & $34.4 \mathrm{c}$ & $-3.5 \mathrm{c}$ & $33.3 \mathrm{a}$ & $3.1 \mathrm{a}-\mathrm{c}$ & $-2.9 \mathrm{a}$ & $25.8 a$ \\
\hline Overley & $19.4 \mathrm{~d}$ & $27.8 \mathrm{ab}$ & $21.0 \mathrm{~cd}$ & $20.3 b c$ & $47.7 \mathrm{a}$ & $25.1 \mathrm{a}$ & $20.1 \mathrm{a}$ & $39.2 a$ \\
\hline Roane & $39.5 \mathrm{bc}$ & $17.0 \mathrm{~b}$ & $50.0 \mathrm{bc}$ & $43.9 \mathrm{bc}$ & $38.6 \mathrm{a}$ & $-3.4 c$ & $13.6 \mathrm{a}$ & $50.6 a$ \\
\hline Tomahawk & $5.8 \mathrm{e}$ & $22.6 \mathrm{ab}$ & $0.0 \mathrm{~d}$ & $-13.6 c$ & $47.6 \mathrm{a}$ & $19.8 \mathrm{ab}$ & $1.9 \mathrm{a}$ & $24.4 a$ \\
\hline Truman & $65.7 \mathrm{a}$ & $23.3 \mathrm{ab}$ & $80.0 \mathrm{a}$ & $61.8 \mathrm{a}$ & $46.2 \mathrm{a}$ & $9.1 \mathrm{a}-\mathrm{c}$ & $34.8 \mathrm{a}$ & $59.2 a$ \\
\hline
\end{tabular}

y Experiments were conducted at Manhattan, KS in 2008 and 2009 and consisted of six winter wheat cultivars and two fungicide treatments: check and prothioconazole + tebuconazole (Prosaro) applied at 0.475 liter/ha.

${ }^{\mathrm{z}}$ Means followed by the same letter within a column are not different according to Fisher's least significant difference test at $P=0.05$. 
FHB index, incidence, severity, and FDK. They found that more than $65 \%$ of correlation coefficients were $>0.50$. They found that the strongest relationship was between FDK and DON. However, in this study, the strongest relationship was consistently between index and DON. This difference may be due to the fact that we used a much smaller data set than they did. In addition, our data were all from winter wheat cultivars, whereas their larger data set included several different wheat types. Menniti et al. (11) also found a positive linear correlation between FDK and DON. As expected, this study showed that yield and index, yield and FDK, and yield and DON were negatively correlated. Index is a direct indicator of yield loss, whereas DON and FDK are indirect indicators.

Two methods were used to measure FDK in this study: a singlekernel near-infrared (SKNIR) system (experiments 2 and 3) and visual estimation (experiments 1, 4, and 5). The method of FDK measurement did not affect correlation analysis involving FDK, as correlation coefficients were similar in the two sets of experiments (Table 6). Wegulo and Dowell (21) showed that the SKNIR system measured FDK in winter wheat with accuracy similar to that of human raters, and was more consistent and detected FDK over a wider range than human raters.
The effect of winter wheat cultivar resistance/susceptibility on the relationships among FHB index, yield, FDK, and DON has not been studied previously. This study suggests a stronger correlation between index and DON, index and FDK, and FDK and DON in susceptible than in moderately resistant cultivars. In contrast, correlation between yield and FDK and between yield and DON was stronger in moderately resistant than in susceptible cultivars. More work on larger sets of resistant and susceptible cultivars is needed to verify our findings and to decipher the reasons for the differences between moderately resistant and susceptible winter wheat cultivars in the effects they have on the relationships among FHB index, yield, FDK, and DON. Researchers aspiring to model relationships among index, DON, FDK, and yield can use this information to choose cultivars that are suitable to their specific objectives.

The finding in this study that fungicide efficacy in reducing FHB index, DON, and FDK was higher in moderately resistant compared to susceptible winter wheat cultivars (Fig. 1) is consistent with the results of previous studies $(13,18)$. This finding suggests that integrating cultivar resistance with fungicide application can be an effective strategy for managing FHB. In years with high FHB

Table 6. Correlation coefficients ${ }^{\mathrm{u}}$ for Fusarium head blight (FHB) index, yield, Fusarium-damaged kernels (FDK), and deoxynivalenol (DON) concentration from experiments conducted to determine the effect of combining cultivar resistance and fungicide application on FHB, yield, FDK, and DON in winter wheat ${ }^{\mathrm{v}}, 2007$ to 2009

\begin{tabular}{|c|c|c|c|c|c|c|c|c|}
\hline \multirow[b]{2}{*}{ Variables } & \multicolumn{4}{|c|}{ Experiments 1 to 3} & \multicolumn{4}{|c|}{ Experiments 4 and 5} \\
\hline & $\begin{array}{c}\text { Cultivar } \\
N=9^{\mathrm{w}}\end{array}$ & $\begin{array}{l}\text { Fungicide } \\
\text { treatment } \\
\qquad N=9^{\mathrm{x}}\end{array}$ & $\begin{array}{c}\text { Check } \\
\text { treatment } \\
N=9^{y}\end{array}$ & $\begin{array}{c}\text { Fungicide } \\
\text { and check } \\
\qquad N=1^{\mathrm{z}}\end{array}$ & $\begin{array}{l}\text { Cultivar } \\
N=12^{w}\end{array}$ & $\begin{array}{c}\text { Fungicide } \\
\text { treatment } \\
N=12^{\mathrm{x}}\end{array}$ & $\begin{array}{c}\text { Check } \\
\text { treatment } \\
N=12^{y}\end{array}$ & $\begin{array}{c}\text { Fungicide } \\
\text { and check } \\
\qquad N=24^{\mathrm{z}}\end{array}$ \\
\hline Index/yield & -0.40 & -0.26 & -0.51 & -0.41 & $-0.77 * *$ & $-0.80 * *$ & $-0.74 * *$ & $-0.78 * * * *$ \\
\hline Index/FDK & 0.59 & $0.76^{*}$ & 0.34 & 0.55 & 0.59 & $0.54 *$ & $0.63 *$ & $0.59 * *$ \\
\hline Index/DON & $0.81 * *$ & $0.74 *$ & $0.85 * *$ & $0.81 * *$ & $0.84 * * *$ & $0.88 * * *$ & $0.77 * *$ & $0.84 * * * *$ \\
\hline Yield/FDK & -0.16 & -0.24 & -0.12 & -0.30 & -0.51 & -0.55 & -0.47 & $-0.52 * *$ \\
\hline Yield/DON & -0.64 & -0.59 & $-0.67 *$ & $-0.63^{*}$ & $-0.74 * *$ & $-0.78^{* *}$ & $-0.69^{*}$ & $-0.75 * * * *$ \\
\hline FDK/DON & 0.63 & $0.70 *$ & 0.51 & 0.59 & 0.44 & 0.45 & 0.44 & $0.46^{*}$ \\
\hline
\end{tabular}

$\mathrm{u} *, * *, * * *, * * * *$ : Correlation coefficients significant at $0.01<P \leq 0.05,0.001<P \leq 0.01,0.0001<P \leq 0.001$, and $P<0.0001$, respectively.

${ }^{v}$ Experiments were conducted in five location-years (Manhattan, KS, 2007 to 2009, and Mead, NE, 2008 to 2009 ) and consisted of a total of nine winter wheat cultivars and two fungicide treatments: check and prothioconazole + tebuconazole (Prosaro) applied at 0.475 liter/ha.

${ }^{w}$ Correlation analysis used 9 means [3 cultivars (2137, Harry, Jagalene) $\times 3$ location-years] and 12 means [6 cultivars (Heyne, Karl 92, Overley, Roane, Tomahawk, Truman) $\times 2$ location-years]; cultivar means averaged over all fungicide treatments.

${ }^{x}$ Correlation analysis used 9 means [3 cultivars (2137, Harry, Jagalene) $\times 3$ location-years] and 12 means [6 cultivars (Heyne, Karl 92, Overley, Roane, Tomahawk, Truman) $\times 2$ location-years]; means from fungicide treatments only.

y Correlation analysis used 9 means [3 cultivars (2137, Harry, Jagalene) $\times 3$ location-years] and 12 means [6 cultivars (Heyne, Karl 92, Overley, Roane, Tomahawk, Truman) $\times 2$ location-years]; means from check treatments only.

${ }^{\mathrm{z}}$ Correlation analysis used 18 means [ 3 cultivars $(2137$, Harry, Jagalene) $\times 3$ location-years $\times 2$ fungicide treatments] and 24 means [6 cultivars (Heyne, Karl 92, Overley, Roane, Tomahawk, Truman) $\times 2$ location-years $\times 2$ fungicide treatments].

Table 7. Correlation coefficients ${ }^{\mathrm{u}}$ for Fusarium head blight (FHB) index, yield, Fusarium-damaged kernels (FDK), and deoxynivalenol (DON) concentration in susceptible and moderately resistant cultivars from experiments conducted to determine the effect of combining cultivar resistance and fungicide application on FHB, yield, FDK, and DON in winter wheat ${ }^{\mathrm{v}}, 2007$ to 2009

\begin{tabular}{|c|c|c|c|c|c|c|c|c|}
\hline \multirow[b]{2}{*}{ Variables } & \multicolumn{2}{|c|}{ Cultivarw $^{w}$} & \multicolumn{2}{|c|}{ Fungicide treatment ${ }^{x}$} & \multicolumn{2}{|c|}{ Check treatmenty } & \multicolumn{2}{|c|}{ Fungicide and $\operatorname{check}^{\mathrm{z}}$} \\
\hline & $\begin{array}{c}\text { Susceptible } \\
\qquad N=10\end{array}$ & $\begin{array}{c}\text { Moderately } \\
\text { resistant } \\
N=9\end{array}$ & $\begin{array}{l}\text { Susceptible } \\
\qquad N=\mathbf{1 0}\end{array}$ & $\begin{array}{c}\text { Moderately } \\
\text { resistant } \\
N=9\end{array}$ & $\begin{array}{c}\text { Susceptible } \\
\qquad N=\mathbf{1 0}\end{array}$ & $\begin{array}{c}\text { Moderately } \\
\text { resistant } \\
N=9\end{array}$ & $\begin{array}{c}\text { Susceptible } \\
\quad N=\mathbf{2 0}\end{array}$ & $\begin{array}{c}\text { Moderately } \\
\text { resistant } \\
N=18\end{array}$ \\
\hline Index/yield & 0.14 & 0.01 & -0.48 & 0.08 & -0.33 & -0.20 & -0.43 & -0.19 \\
\hline Index/FDK & $0.67 *$ & -0.10 & $0.65^{*}$ & 0.19 & 0.59 & -0.21 & $0.64 * *$ & 0.10 \\
\hline Index/DON & $0.84 * *$ & 0.49 & $0.83 * *$ & 0.34 & $0.83 * *$ & 0.61 & $0.83 * * * *$ & $0.62 * *$ \\
\hline Yield/FDK & 0.60 & $-0.74 *$ & -0.11 & -0.54 & 0.17 & -0.57 & -0.07 & $-0.58 *$ \\
\hline Yield/DON & 0.54 & -0.31 & -0.26 & -0.61 & -0.02 & -0.54 & -0.17 & $-0.60 * *$ \\
\hline FDK/DON & $0.69 *$ & -0.16 & $0.72 *$ & -0.05 & 0.62 & -0.20 & 0.67 & -0.02 \\
\hline
\end{tabular}

$\mathrm{u} *, * *, * * *, * * * *$ : Correlation coefficients significant at $0.01<P \leq 0.05,0.001<P \leq 0.01,0.0001<P \leq 0.001$, and $P<0.0001$, respectively.

${ }^{v}$ Experiments were conducted in five location-years (Manhattan, KS, 2007 to 2009 and Mead, NE, 2008 to 2009) and consisted of a total of nine winter wheat cultivars and two fungicide treatments: check and prothioconazole + tebuconazole (Prosaro) applied at 0.475 liter/ha. Correlation analysis used 10 means for susceptible cultivars $(2137 \times 3$ location-years + Jagalene $\times 3$ location-years + Overley $\times 2$ location-years + Tomahawk $\times 2$ location-years $)$ and 9 means for moderately resistant cultivars (Harry $\times 3$ location-years + Heyne $\times 2$ location-years + Roane $\times 2$ location-years + Truman $\times 2$ location-years).

${ }^{w}$ Cultivar means averaged over all fungicide treatments were used in correlation analysis.

${ }^{x}$ Means from fungicide treatments only were used in correlation analysis.

y Means from check treatments only were used in correlation analysis.

${ }^{\mathrm{z}}$ Correlation analysis used 20 means for susceptible cultivars (fungicide treatments + check treatments) and 18 means for moderately resistant cultivars (fungicide treatments + check treatments) 
intensity, the combination of moderately resistant cultivars with fungicide application is necessary to reduce FHB to acceptable levels with respect to yield, test weight, and DON accumulation. In years with low to moderate FHB intensity, it may not be necessary to apply a fungicide if moderately resistant cultivars are grown because the resistance alone may be sufficient to prevent economic loss, resulting in time and money savings for producers. Moreover, because FHB is controlled with greater efficacy on moderately resistant cultivars, inoculum buildup over time is likely to be reduced when moderately resistant cultivars are grown.

\section{Acknowledgment and Disclaimer}

This material is based upon work supported by the U.S. Department of Agriculture, under Agreement No. 59-0790-7-080. This is a cooperative project with the U.S. Wheat \& Barley Scab Initiative. Any opinions, findings, conclusions, or recommendations expressed in this publication are those of the author(s) and do not necessarily reflect the view of the U.S. Department of Agriculture

\section{Literature Cited}

1. De Wolf, E. D., Bockus, W. W., and Whitworth, J. R. 2010. Wheat Variety Disease and Insect Ratings 2010. MF-991. Kansas State University Agricultural Experiment Station and Cooperative Extension Service, Manhattan, KS.

2. Dill-Macky, R. 2010. Fusarium head blight (scab). Pages 34-36 in: Compendium of Wheat Diseases and Pests. W. W. Bockus, R. L. Bowden, R. M. Hunger, W. L. Morrill, T. D. Murray, and R. W. Smiley, eds. American Phytopathological Society, St. Paul, MN.

3. Gomez, A. K., and Gomez, A. A. 1984. Statistical Procedures for Agricultural Research, 2nd ed. John Wiley \& Sons, New York.

4. Gregoire, T. D. 2002. An extension agronomist's experiences with fungicide application techniques to improve control of FHB. Page 76 in: Proc. Nat. Fusarium Head Blight Forum. S. M. Canty, J. Lewis, L. Siler, and R. W. Ward, eds. Erlanger, KY.

5. Hollingsworth, C. R., Mottenberg, C. D., and Thompson, W. G. 2006. Assessing fungicide efficacies for the management of Fusarium head blight on spring wheat and barley. Online publication. Plant Health Progress doi:10.1094/PHP-2006-0906-01-RS.

6. Horsley, R. D., Pederson, J. D., Schwarz, P. B., McKay, K., Hochhalter, M. R., and McMullen, M. P. 2006. Integrated use of tebuconazole and Fusarium head blight-resistant barley genotypes. Agron. J. 98:194-197.

7. Ioos, R., Belhadj, A., Menez, M., and Faure, A. 2005. The effects of fungicides on Fusarium spp. and Microdochium nivale and their associated tricothecene mycotoxins in French naturally-infected cereal grains. Crop Prot. 24:894-902.

8. Jones, R. K. 2000. Assessments of Fusarium head blight of wheat and barley in response to fungicide treatment. Plant Dis. 84:1021-1030.

9. Koch, H.-J., Pringas, C., and Maerlaender, B. 2006. Evaluation of environmental and management effects on Fusarium head blight infection and deoxynivalenol concentration in the grain of winter wheat. Eur. J. Agron. 24:357-366.

10. McMullen, M., Jones, R., and Gallenberg, D. 1997. Scab of wheat and barley: A re-emerging disease of devastating impact. Plant Dis. 81:13401348.

11. Menniti, A. M., Pancaldi, D., Maccaferri, M., and Casalini, L. 2003. Effect of fungicides on Fusarium head blight and deoxynivalenol content in durum wheat grain. Eur. J. Plant Pathol. 109:109-115.

12. Mesterhazy, A. 2003. Control of Fusarium head blight of wheat by fungicides. Pages 363-380 in: Fusarium Head Blight of Wheat and Barley. K. J. Leonard and W. Bushnell, eds. American Phytopathological Society, St. Paul, MN.

13. Mesterhazy, A., Bartok, T., and Lamper, C. 2003. Influence of wheat cultivar, species of Fusarium, and isolate aggressiveness on the efficacy of fungicides for control of Fusarium head blight. Plant Dis. 87:1107-1115

14. Mesterhazy, A., Bartok, T., Mirocha, C. G., and Komoroczy, R. 1999. Nature of wheat resistance to Fusarium head blight and the role of deoxynivalenol for breeding. Plant Breed. 118:97-110.

15. Milus, E. A., and Parsons, C. E. 1994. Evaluation of foliar fungicides for controlling Fusarium head blight of wheat. Plant Dis. 78:697-699.

16. Parry, D. W., Jenkinson, P., and McLeod, L. 1995. Fusarium ear blight (scab) in small grain cereals - a review. Plant Pathol. 44:207-238.

17. Paul, P. A., Lipps, P. E., and Madden, L. V. 2005. Relationship between visual estimates of Fusarium head blight intensity and deoxynivalenol accumulation in harvested wheat grain: A meta-analysis. Phytopathology 95:1225-1236.

18. Ransom, J. K., and McMullen, M. P. 2008. Yield and disease control on hard winter wheat cultivars with foliar fungicides. Agron. J. 100:1130-1137.

19. Steel, R. G. D., Torrie, J. H., and Dickey, D. A. 1997. Principles and Procedures of Statistics: A Biometrical Approach, 3rd ed. McGraw-Hill, New York.

20. Tacke, B. K., and Casper, H. H. 1996. Determination of deoxynivalenol in wheat, barley, and malt by column cleanup and gas chromatography with electron capture detection. J. Assoc. Off. Anal. Chem. 79:472-475.

21. Wegulo, S. N., and Dowell, F. E. 2008. Near-infrared versus visual sorting of Fusarium-damaged kernels in winter wheat. Can. J. Plant Sci. 88:10871089.

22. Zadoks, J. C., Chang, T. T., and Konzak, C. F. 1974. A decimal code for the growth stages of cereals. Weed Res. 14:415-421. 